\title{
Criminal victimisation and health: Examining the relation in nine countries of the former Soviet Union
}

\author{
Andrew Stickley ${ }^{\mathrm{a}, \mathrm{b}, *}$, Ai Koyanagi ${ }^{\mathrm{b}}$, Bayard Roberts ${ }^{\mathrm{a}}$, David Rotman ${ }^{\mathrm{c}}$, Martin McKee ${ }^{\mathrm{a}}$ \\ ${ }^{a}$ European Centre on Health of Societies in Transition, London School of Hygiene and Tropical Medicine, 15-17 Tavistock Place, London WC1H 9SH, United \\ Kingdom \\ ${ }^{\mathrm{b}}$ Stockholm Centre on Health of Societies in Transition (SCOHOST), Södertörn University, 14189 Huddinge, Sweden \\ ${ }^{\mathrm{c}}$ Centre for Sociological and Political Research, Belarussian State University, Minsk, Belarus
}

\section{A R T I C L E I N F O}

\section{Article history:}

Available online 13 May 2013

\section{Keywords:}

Former Soviet Union

Crime

Self-rated health

Psychological distress

Violence

Victimisation

\begin{abstract}
A B S T R A C T
Previous research suggests that criminal victimisation can impact negatively on both physical and psychological health. However, as yet, little is known about crime and its effects on population health in the former Soviet Union (fSU) - despite a sharp growth in crime rates in the countries in this region after the collapse of the communist system. Given this gap in current knowledge, this study examined two forms of crime, theft and violent victimisation, in nine fSU countries - Armenia, Azerbaijan, Belarus, Georgia, Kazakhstan, Kyrgyzstan, Moldova, Russia and Ukraine. Using nationally representative data from the Health in Times of Transition (HITT) study collected from 18,000 respondents in 2010/11, the study had two main objectives: (1) to identify which demographic and socioeconomic factors are associated with being a victim of crime; (2) to examine the relation between criminal victimisation and two health outcomes - self-rated health and psychological distress. We found that similar factors were associated with experiencing both forms of crime among respondents. Those who were younger, not married and who consumed alcohol more frequently were at increased risk of victimisation, while greater social capital was associated with lower odds for victimisation. Low education increased the risk of experiencing violence by 1.5 times. Victimisation was strongly associated with poorer health: victims of violence were 2.5 and 2.9 times more likely to report poor self-rated health and psychological distress, respectively, while the corresponding figures for theft victimisation were 1.9 and 1.8. The strong association we observed between criminal victimisation and poorer individual health suggests that, in addition to policies that reduce rates of crime, more research is now urgently needed on victimisation. Specifically, researchers should ascertain whether the association with poor health is causal, determine its potential mechanisms, and evaluate interventions that might mitigate its impact on health that are contextually appropriate in the fSU.
\end{abstract}

(c) 2013 Elsevier Ltd. All rights reserved.

\section{Introduction}

The collapse of the communist system and subsequent social, economic and political transformation that has occurred in the countries of the former Soviet Union (fSU) has coincided with sharp fluctuations in population health in the period since the early 1990s. A mortality crisis marked by steep and unprecedented reductions in life expectancy in many countries in the first phase of transition (1991-1994) gave way, initially, to a series of fluctuations and, more recently to gradual improvements in life expectancy in all of the countries. Nevertheless, even as late as in 2009, life

\footnotetext{
* Corresponding author. Stockholm Centre on Health of Societies in Transition (SCOHOST), Södertörn University, 14189 Huddinge, Sweden. Tel.: +46 8608 4689; fax:+46 86083040 .

E-mail address: andrew.stickley@sh.se (A. Stickley).
}

expectancy at birth was only back at its 1990 level throughout the Commonwealth of Independent States (69.5 vs. 69.7 years) and still lower than its initial level in Russia, Ukraine and Belarus (World Health Organization, 2012). These changes have stimulated much research - particularly in Russia - which has aimed to identify those factors underlying these rapid shifts in population well-being (Brainerd \& Cutler, 2005; Murphy, 2011). Although proximal factors such as hazardous drinking, smoking, and poor nutrition (Leon et al., 2007, Leon, Shkolnikov \& McKee, 2009; World Bank, 2005) and more distal ones such as psychosocial stress (Brainerd, \& Cutler, 2005) and the pace of transition (Stuckler, King \& McKee, 2009) are all recognised as important, there are still many aspects of the poor health seen in this region that are inadequately understood (Brainerd \& Cutler, 2005).

One element which has been relatively absent from the research on population health in the countries in this region has been the 
role of crime. This is surprising for several reasons. The same conditions which underpinned the sharp growth in all-cause mortality in the early transition period - rising unemployment and increasing inequality, widespread impoverishment and the removal of social safety nets in the presence of weakened states and greater alcohol consumption - have also been linked to the sharp growth in crime that took place at this time (Foglesong \& Solomon, 2001; Gilinskiy, 2006; Holmes, 2009; Karstedt, 2003). In particular, there was a startling increase in murder rates in many fSU countries following the collapse of the Soviet Union (Chervyakov, Shkolnikov, Pridemore \& McKee, 2002; Gavrilova, Semyonova, Evdokushkina \& Gavrilov, 2000; Stickley, Leinsalu \& Razvodovsky, 2009). However, the rise in crime was not limited to lethal violence as the data suggest that there were also large increases in various types of nonlethal violence (e.g. grievous bodily harm, assault) (Gilinskiy, 2006; Van Dijk \& Chanturia, 2011), as well as in other forms of crime, such as property crime (e.g. theft and robbery) (Solomon \& Foglesong, 2000; Van Dijk \& Chanturia, 2011).

Importantly, what evidence there is does suggest that high and increasing rates of crime may have been a significant factor in the deterioration in population health in the countries in this region, at least in the early transition period. Two previous ecological studies have linked crime to falling life expectancy and increasing death rates at this time (Brainerd, 1998; Walberg, McKee, Shkolnikov, Chenet \& Leon, 1998). However, to the best of our knowledge, until now, there has been no attempt to examine the victimisationhealth relationship at the individual level across the countries in this region. This is an important research gap as a growing body of evidence from other settings has highlighted how the effects of being a victim of crime can be extremely detrimental for the health of the affected individual (Britt, 2001; Robinson \& Keithley, 2000; Shapland \& Hall, 2007). Both violent (Breiding, Black \& Ryan, 2008; Campbell, 2002; Ellsberg, Jansen, Heise, Watts, Garcia-Moreno, 2008) and non-violent forms of criminal victimisation (Beaton, Cook, Kavanagh \& Herrington, 2000; Britt, 2001) have been linked to a wide variety of negative physical and psychological health outcomes including bodily injuries, pain, fear, panic, anxiety, depression, and posttraumatic stress disorder (PTSD) (Campbell, 2002; Kilpatrick \& Acierno, 2003; Shapland \& Hall, 2007). Victimisation has also been linked to poorer self-rated health. A study from 15 different sites in 10 countries showed that women who reported experiencing lifetime intimate partner violence were 1.6 times more likely to report their health as being poor or very poor compared to women who had never experienced violence (Ellsberg et al., 2008). This relation has also been observed among younger (Romito \& Grassi, 2007) and older men (Olofsson, Lindqvist \& Danielsson, 2012). As yet, there has been less research on the relation between non-violent crime and perceptions of health among adults. An earlier study did show however, that women who were 'mildly victimised' i.e. the victim of either a non-contact crime such as burglary or an attempted crime were more likely to report poorer self-rated health (although this crime category also included attempted rape) (Koss, Woodruff \& Koss, 1990). In addition, research has also highlighted how these detrimental health effects can be long lasting (Norris \& Kaniasty, 1994), as can the social and economic consequences arising from victimisation (Robbins, 2007).

Against this background the aim of the current study was twofold. First, to identify what factors are associated with criminal victimisation in the countries in this region. Previous research from the West has shown that the risk of (especially violent) criminal victimisation is not distributed equally throughout populations (Faergemann, Lauritsen, Brink, Skov \& Mortensen, 2009; Kilpatrick \& Acierno, 2003; Stickley \& Carlson, 2010; Thacher, 2004) and can be related to different demographic ('lifestyle') (Hindelang, Gottfredson \& Garofalo, 1978) and residential characteristics
(Brennan, Moore \& Shepherd, 2010; Kilpatrick \& Acierno, 2003). Understanding exactly who is a victim of crime is important as it has been suggested that the relationship between crime and health is complex in that it can be affected by individual (e.g. sex, age, personality), situational (e.g. other life events) and crime-related factors (e.g. type of crime and/or perceived threat to life) (Kilpatrick \& Acierno, 2003; Shapland \& Hall, 2007). Second, we will examine the relationship between victimisation and two health outcomes - self-rated health and psychological distress. Even though some research indicates that the crime situation may have improved in several fSU countries in the past decade (Holmes, 2009; Slade, 2012; Van Dijk \& Chanturia, 2011), the potential importance of this research is nonetheless suggested by a recent study which has highlighted how even 'concern' about crime is currently impacting negatively on psychological well-being in the countries in this region (Roberts, Stickley, Petticrew \& McKee, 2012).

\section{Methods}

\section{Study population}

The data used in this study were drawn from the Health in Times of Transition (HITT) survey (www.hitt-cis.net). HITT was a multicountry cross-sectional survey undertaken in Armenia, Azerbaijan, Belarus, Georgia, Kazakhstan, Kyrgyzstan, Moldova, Russia, and Ukraine between March and May 2010 (with the data collection in Kyrgyzstan delayed until early 2011 because of political violence). In each country a nationally representative household survey was conducted using multi-stage random sampling. Within each primary sampling unit (about 100-200 per country), households were selected by random route procedures, with one person aged 18 and above being randomly chosen from each household (according to the nearest birthday). Face-to-face interviews were conducted by trained interviewers in the respondents' homes using a questionnaire that was translated into each of the national languages in which it was administered (with all respondents having the choice of answering in either their country's own language or Russian - except for in Russia and Belarus where only Russian was used).

There were 1800 respondents per country, except for in Russia $(n=3000)$ and Ukraine $(n=2000)$ where the sample size was bigger to reflect their larger and more regionally diverse populations. A larger sample was also gathered from Georgia $(n=2200)$ after a booster survey of 400 additional interviews was undertaken in November 2010 to ensure a more representative sample. Response rates varied from $47 \%$ in Kazakhstan to $83 \%$ in Moldova. The research was approved by the ethics committee of the London School of Hygiene and Tropical Medicine and was carried out in accordance with the 1975 Helsinki Declaration.

\section{Study variables}

\section{(1) Outcome variables}

Information was obtained on physical violence and theft by asking respondents, 'During the past 12 months, have you been a victim of physical violence?' and 'During the past 12 months has anything been stolen from you?'. Those respondents who answered 'Yes' were classified as being a victim of violence and theft, respectively.

Using previous literature as a guide, two main health outcomes were examined: self-rated health and psychological distress. Selfrated health was assessed by asking, 'In general, would you say your health is...' and requiring respondents to choose one answer option from the response categories 'Very good', 'Good', 'Fair', 'Poor' 
and 'Very poor'. Poor self-rated health (i.e. poor/very poor) was the object of focus and scored ' 1 ' while better than poor health (i.e. fair/ good/very good) was scored ' 0 '. To assess psychological distress we employed a measure that has been used in several previous studies in the countries in this region (Cockerham, Hinote \& Abbott, 2006; Roberts et al., 2012). This scale consisted of 12 items that encompass a range of negative psychological feelings: 'inability to concentrate', 'insomnia', 'constant feelings of strain' 'inability to overcome difficulties', 'losing confidence', 'shaking nervously or trembling', 'having frightening thoughts', 'experiencing exhaustion or fatigue', 'feeling stress', 'feeling an impossibility to influence things', 'feeling lonely' and 'feeling that life is too complicated'. For each item subjects could answer either 'Yes' or 'No' if they had experienced the symptom in recent weeks. This created a composite psychological distress score running from 0 to 12 . For the psychological distress outcome those subjects who fell into the top quintile of scores in terms of suffering most distress (which equated to a score of 6 and above on the psychological distress scale) were scored ' 1 ' while the remainder of the subjects were scored ' 0 '.

\section{(2) Independent variables}

Age was divided into three bands - 18 to 39,40 to 64 , and 65 and above. In a similar fashion, 'Education' was divided into three categories, 'High' (complete/incomplete higher education), 'Middle' (complete secondary education) and 'Low' (less than complete secondary education). In terms of their marital status, respondents were categorised as being either 'Married/cohabiting', 'Never married' (single) or 'Divorced/Widowed'. As there are problems with using income as a measure of wealth in the countries in this region because of the late/non-payment of wages or because of 'payment-in-kind' (Earle \& Sabirianova, 2002; Gerry, Kim \& Li, 2004; Schwartz, 2003), in this study we used an asset index to assess subjects' material well-being. This index consisted of 10 items including such things as a refrigerator, television, computer, car etc. Principal component analysis was used to generate three wealth tertiles based on asset ownership which were labelled 'High', 'Middle' and 'Low. For residential location, respondents were categorised as living in either 'Urban' or 'Rural' areas. Previous research has suggested that social capital may be associated with victimisation in this region (Stickley \& Pridemore, 2010). We therefore examined this association in the current analysis using a question which assessed how often the respondents met socially with 'close relatives', 'friends' and 'neighbours'. This question had seven response categories ranging from 'Never' (scored 1 ) to 'Every day' (scored 7). These measures were examined as 3 continuous variables. In addition, as alcohol consumption may be linked to violent victimisation in some of our study countries (Stickley \& Pridemore, 2010), we included the frequency of alcohol consumption in our analysis where respondents were categorised as 'Never' drinking alcohol, consuming it ' $1-2$ times a month or less', 'Once a week' or ' $2-3$ times a week or more often'.

Finally, smoking, unemployment and BMI (body mass index) were included in our analysis of the effect of criminal victimisation on health outcomes as previous research has suggested that they may impact on physical and/or psychological health (Breslau, Peterson, Schultz, Chilcoat \& Andreski, 1998; Manderbacka, Lahelma \& Martikainen, 1998; McKee-Ryan, Song, Wanberg \& Kinicki, 2005). Those respondents who smoked at least one cigarette (papirossi, pipe, cigar etc.) per day were categorised as 'Smokers'. For unemployment a 3-category variable was created where 'Unemployed, seeking work' was categorised as '1', 'Unemployed, not seeking work' was categorised as '2', while all forms of 'Occupation' were categorised as '0'. Self-reported height and weight were used to create a BMI measure. Its three categories were: 'Normal weight' (i.e. $<25 \mathrm{~kg} / \mathrm{m}^{2}$ ) scored '0', 'Overweight (i.e. $25-29.9 \mathrm{~kg} / \mathrm{m}^{2}$ ) scored ' 1 ' and 'Obesity' (i.e. $\geq 30 \mathrm{~kg} / \mathrm{m}^{2}$ ) scored '2'.

\section{Statistical analyses}

We assessed the correlates of criminal victimisation, and the association between victimisation and health using logistic regression analysis. The fully adjusted model for the former included sex, age, education, marital status, wealth, location, social capital, alcohol consumption, and country as covariates. For the latter analysis, in addition to the above covariates, smoking, unemployment and BMI were also included in the model. All analyses were carried out using the statistical software package Stata 12.0 (Stata Corp LP, College Station, Texas). All of the results are presented in the form of odds ratios (OR) with 95\% confidence intervals (CI). Two analyses were conducted for all outcomes: (1) adjusted only for country; (2) adjusted for all covariates. The level of statistical significance was set at $p<0.05$.

\section{Results}

The sample characteristics are presented in Table 1 . There were more women than men in every country. This was especially noticeable in Georgia and may reflect greater male labour outmigration (Caucasus Research Resource Centres, 2007). In every country except one, more than $80 \%$ of respondents were aged under 65 , while around one-quarter had received a higher education in the majority of countries. Between $55 \%$ and $69 \%$ of respondents were married across the countries. The prevalence of having a low level of wealth (as assessed by the asset index) varied widely between countries ranging from $19.6 \%$ in Belarus to $46.4 \%$ in Kyrgyzstan. In terms of social capital, there were generally higher scores in all countries for meeting with neighbours compared to friends and relatives, with Georgia being especially noticeable for the greater frequency of meeting with neighbours as opposed to contact with close relatives. The prevalence of consuming alcohol also differed greatly among countries with the percentage abstaining ranging from $13.4 \%$ (Belarus) to $80.4 \%$ (Azerbaijan), while $2.9 \%$ (Kyrgyzstan) to $26.3 \%$ (Moldova) of the respondents drank alcohol at least 2-3 times a week. Being a victim of theft was much more common than experiencing violence. Indeed, the 12month prevalence of violent victimisation only exceeded $2 \%$ in two countries (Kyrgyzstan $-2.2 \%$ and Moldova $-2.6 \%$ ) with the figure being as low as $0.5 \%$ in Georgia (while across all the countries the average figure was $1.5 \%$ ). The prevalence of theft ranged from $2.5 \%$ in Azerbaijan and Georgia to $10.1 \%$ in Moldova with most countries having a figure under $6 \%$ (averaging $5.7 \%$ in the sample overall).

The factors associated with experiencing victimisation are presented in Table 2 . In the fully adjusted model, several variables were associated with increased odds for experiencing violence and theft. Respondents who were aged under 65 had two to three times higher odds of being a victim of physical violence than those aged 65 years and over; while those aged 18-39 had a 1.3 times higher risk of experiencing theft compared with those aged 65 and above. Those respondents with a low level of education had a 1.5 times increased risk of violent victimisation. Being single or divorced carried a 1.3-1.7 times higher risk of experiencing theft/violence when compared with married respondents. In terms of social capital, an increase in the frequency of meeting neighbours (with scores ranging from 1 (never) to 7 (daily)) was associated with a reduced risk of being a victim of both violence and theft. Drinking alcohol once a week increased the risk of having been subjected to violence by 1.7 times when compared with non-drinkers while this figure rose to 2.3 for those drinking at least 2-3 times a week. 
Table 1

Baseline characteristics of the study sample by country $(N=18,000)$.

\begin{tabular}{|c|c|c|c|c|c|c|c|c|c|c|}
\hline Characteristic & Categories & $\begin{array}{l}\text { Armenia } \\
\%\end{array}$ & $\begin{array}{l}\text { Azerbaijan } \\
\%\end{array}$ & $\begin{array}{l}\text { Belarus } \\
\%\end{array}$ & $\begin{array}{l}\text { Georgia } \\
\%\end{array}$ & $\begin{array}{l}\text { Kazakhstan } \\
\%\end{array}$ & $\begin{array}{l}\text { Kyrgyzstan } \\
\%\end{array}$ & $\begin{array}{l}\text { Moldova } \\
\%\end{array}$ & $\begin{array}{l}\text { Russia } \\
\%\end{array}$ & $\begin{array}{l}\text { Ukraine } \\
\%\end{array}$ \\
\hline \multirow[t]{2}{*}{ Sex } & Male & 45.7 & 47.0 & 43.6 & 36.4 & 47.4 & 48.3 & 44.3 & 40.4 & 42.2 \\
\hline & Female & 54.3 & 53.0 & 56.4 & 63.6 & 52.6 & 51.7 & 55.7 & 59.6 & 57.8 \\
\hline \multirow[t]{3}{*}{ Age (years) } & $\geq 65$ & 8.0 & 5.6 & 14.3 & 16.6 & 10.5 & 7.2 & 13.2 & 16.2 & 20.5 \\
\hline & $40-64$ & 40.9 & 41.1 & 38.4 & 44.5 & 36.0 & 35.4 & 42.7 & 42.1 & 38.2 \\
\hline & $18-39$ & 51.1 & 53.4 & 47.2 & 38.9 & 53.5 & 57.4 & 44.1 & 41.7 & 41.4 \\
\hline \multirow[t]{3}{*}{ Education $^{\mathrm{a}}$} & High & 22.0 & 24.8 & 25.7 & 38.4 & 28.7 & 23.2 & 23.0 & 26.2 & 33.6 \\
\hline & Middle & 69.2 & 67.7 & 66.6 & 53.7 & 59.9 & 53.5 & 49.1 & 61.0 & 54.9 \\
\hline & Low & 8.8 & 7.5 & 7.7 & 8.0 & 11.4 & 23.3 & 27.9 & 12.9 & 11.5 \\
\hline \multirow[t]{3}{*}{ Marital status } & Married/cohabiting & 65.4 & 65.4 & 55.5 & 63.1 & 62.7 & 68.9 & 62.4 & 59.7 & 57.2 \\
\hline & Never married & 26.2 & 27.2 & 23.8 & 17.9 & 21.9 & 18.9 & 17.5 & 17.2 & 17.8 \\
\hline & Divorced/widowed & 8.3 & 7.4 & 20.7 & 19.0 & 15.4 & 12.2 & 20.1 & 23.2 & 25.0 \\
\hline \multirow[t]{3}{*}{ Wealth ${ }^{\mathrm{b}}$} & Low & 34.7 & 26.4 & 19.6 & 39.6 & 33.8 & 46.4 & 45.7 & 24.8 & 33.7 \\
\hline & Middle & 36.4 & 59.2 & 29.6 & 36.6 & 36.6 & 38.5 & 25.6 & 30.1 & 29.2 \\
\hline & High & 28.9 & 14.4 & 50.9 & 23.8 & 29.6 & 15.1 & 28.7 & 45.1 & 37.2 \\
\hline Location & Rural & 22.6 & 43.6 & 26.5 & 52.2 & 44.4 & 54.4 & 61.8 & 27.4 & 30.2 \\
\hline Social capital $^{\mathrm{c}}$ & Close relatives & 4 & 4 & 5 & 3 & 5 & 4 & 4 & 5 & 5 \\
\hline \multirow[t]{2}{*}{ (Median) } & Friends & 6 & 5 & 5 & 5 & 5 & 5 & 5 & 5 & 5 \\
\hline & Neighbours & 6 & 6 & 5 & 7 & 6 & 7 & 6 & 6 & 6 \\
\hline \multirow[t]{4}{*}{ Alcohol consumption } & Never & 24.8 & 80.4 & 13.4 & 29.7 & 33.3 & 49.9 & 16.2 & 22.1 & 22.7 \\
\hline & $1-2$ times/month or less & 61.9 & 14.1 & 65.1 & 55.8 & 52.3 & 45.8 & 49.3 & 55.5 & 52.7 \\
\hline & Once a week & 6.1 & 1.8 & 12.2 & 7.0 & 7.8 & 1.4 & 8.3 & 13.1 & 11.7 \\
\hline & $2-3$ times/week or more & 7.1 & 3.7 & 9.3 & 7.5 & 6.6 & 2.9 & 26.3 & 9.3 & 12.8 \\
\hline Victim of physical violence ${ }^{\mathrm{d}}$ & Yes & 0.7 & 1.9 & 0.8 & 0.5 & 1.7 & 2.2 & 2.6 & 1.3 & 1.9 \\
\hline Victim of theft ${ }^{\mathrm{d}}$ & Yes & 3.8 & 2.5 & 5.8 & 2.5 & 6.4 & 5.9 & 10.1 & 5.4 & 9.1 \\
\hline Poor self-rated health & Yes & 11.7 & 16.6 & 14.8 & 36.9 & 9.6 & 11.6 & 23.7 & 16.1 & 22.1 \\
\hline Psychological distress ${ }^{\mathrm{e}}$ & Yes & 21.2 & 14.8 & 22.6 & 24.2 & 13.9 & 27.0 & 30.0 & 17.7 & 23.7 \\
\hline
\end{tabular}

${ }^{a}$ Education was classified as: low (less than complete secondary education), middle (completed secondary education), high (incomplete or complete higher education).

b Principal component analysis was used to generate the wealth index based on the possession of 10 household assets.

c Social capital was assessed by asking how often the respondent met socially with close relatives, friends and neighbours with the answer options: (1) never, (2) less than once a month, (3) once a month, (4) several times a month, (5) once a week, (6) several times a week, (7) everyday. The median value of this variable is presented.

d Refers to events which occurred in the past 12 months.

e Psychological distress was defined as the highest quintile of a composite score based on 12 questions.

A linear relation was also noted for alcohol consumption and theft with odds for victimisation running from 1.3 (95\% CI: 1.1-1.5) for those drinking 1-2 times a month or less often to 1.8 (95\% CI: 1.4-2.3) for respondents drinking at least 2-3 times a week.

As regards the health outcomes examined, the prevalence of poor-self rated health in 8 countries ranged from 9.6\% (Kazakhstan) to $23.7 \%$ (Moldova). However, a much higher figure was recorded in Georgia (36.9\%). For psychological distress, even using the top quintile resulted in some variation in scores across the countries, with 6 countries scoring between 20.0\% and 30.0\% (Armenia, Belarus, Georgia, Kyrgyzstan, Moldova and Ukraine) while three countries scored under 20.0\% (Azerbaijan, Kazakhstan and Russia) (see Table 1). There was no strong correlation observed between poor self-rated health and psychological distress in this study (kappa coefficient 0.34). The association between criminal victimisation and the health outcomes is shown in Table 3. In the fullyadjusted model the victimisation-poor health relation was statistically significant for both health outcomes. Being a victim of violence or theft thus increased the risk of poor-self rated health by 2.5 and 1.9 times, respectively; and of psychological distress by 2.9 and 1.8 times, respectively.

\section{Discussion}

This is the first multi-country study to examine which factors are associated with experiencing physical violence and theft and their relationship with different health outcomes in the fSU. The prevalence of victimisation was similar across the countries except for in Georgia where rates of victimisation were lower, which may reflect the dramatic reduction in crime that has occurred there in recent years following in the wake of a government-led crackdown on crime (Slade, 2012), and Moldova where they were higher (which interestingly seems to contradict the picture presented by official statistics (Holmes, 2009; UNODC, 2012)). Although theft victimisation was much more widespread than violent victimisation in every country, both forms of victimisation shared a number of common predictors. Specifically, those who were younger and the unmarried were more likely to experience victimisation, as were individuals who consumed alcohol more frequently. Having a low level of education carried a greater risk for violent victimisation while meeting with neighbours more often was linked to a lower risk for both violence and theft victimisation. Both violence and theft victimisation were associated with an increased risk of poorer self-rated health and psychological distress.

Before discussing the main findings from this study it is necessary to mention a number of limitations. We had to rely on self-reports of victimisation and about other variables with the possibility this carries for bias in terms of such issues as providing socially desirable responses (e.g. as regards alcohol consumption). The two victimisation questions were both general in nature and gave no indication of what forms of violence or theft were experienced or of the crime scenarios involved. This is important as some evidence suggests that different types of crime can vary in their impact on health (Boudreaux, Kilpatrick, Resnick, Best \& Saunders, 1998; Kilpatrick et al., 1985). For example, as regards violent victimisation, the effects of interpersonal violence can be much longer lasting and graver than those of stranger violence as it can sometimes involve multiple episodes of victimisation. The fact that the questions related to different time periods is also problematic. While victimisation occurred in the past year, the psychological distress variable referred to symptoms experienced in 'recent weeks'. The low rates of violent victimisation also meant we had to combine men and women in the regression analysis even 
Table 2

Factors associated with criminal victimisation in nine countries of the former Soviet Union.

\begin{tabular}{|c|c|c|c|c|c|c|c|c|c|}
\hline \multirow[t]{3}{*}{ Characteristic } & \multirow[t]{3}{*}{ Categories } & \multicolumn{4}{|c|}{ Victim of physical violence (past 12 months) } & \multicolumn{4}{|c|}{ Victim of theft (past 12 months) } \\
\hline & & \multicolumn{4}{|l|}{$N=17183$} & \multicolumn{4}{|l|}{$N=17143$} \\
\hline & & OR $(95 \% C I)^{a}$ & $P$-value & Adj.OR $(95 \% \mathrm{CI})^{\mathrm{b}}$ & $P$-value & OR $(95 \% C I)^{a}$ & $P$-value & Adj.OR $(95 \% \mathrm{CI})^{\mathrm{b}}$ & $P$-value \\
\hline \multirow[t]{2}{*}{ Sex } & Female & 1.00 & & 1.00 & & 1.00 & & 1.00 & \\
\hline & Male & $1.59(1.24-2.04)$ & $<0.001$ & $1.28(0.98-1.69)$ & 0.074 & $1.04(0.91-1.18)$ & 0.575 & $0.92(0.79-1.06)$ & 0.229 \\
\hline \multirow[t]{3}{*}{ Age (years) } & $\geq 65$ & 1.00 & & 1.00 & & 1.00 & & 1.00 & \\
\hline & $40-64$ & $1.49(0.88-2.53)$ & 0.138 & $1.96(1.11-3.43)$ & 0.019 & $1.24(0.98-1.57)$ & 0.071 & $1.14(0.88-1.47)$ & 0.317 \\
\hline & $18-39$ & $2.47(1.49-4.10)$ & $<0.001$ & $2.92(1.64-5.21)$ & $<0.001$ & $1.66(1.32-2.07)$ & $<0.001$ & $1.34(1.02-1.75)$ & 0.034 \\
\hline \multirow[t]{3}{*}{ Education $^{c}$} & High & 1.00 & & 1.00 & & 1.00 & & 1.00 & \\
\hline & Middle & $0.98(0.73-1.32)$ & 0.918 & $1.09(0.80-1.48)$ & 0.599 & $0.82(0.71-0.95)$ & 0.009 & $0.94(0.80-1.09)$ & 0.416 \\
\hline & Low & $1.27(0.87-1.87)$ & 0.221 & $1.54(1.01-2.35)$ & 0.043 & $0.69(0.56-0.87)$ & 0.001 & $0.87(0.68-1.11)$ & 0.275 \\
\hline \multirow[t]{3}{*}{ Marital status } & Married/cohabiting & 1.00 & & 1.00 & & 1.00 & & 1.00 & \\
\hline & Never married & $2.00(1.51-2.65)$ & $<0.001$ & $1.50(1.09-2.06)$ & 0.014 & $1.50(1.28-1.75)$ & $<0.001$ & $1.28(1.07-1.53)$ & 0.007 \\
\hline & Divorced/widowed & $1.32(0.93-1.85)$ & 0.118 & $1.68(1.16-2.43)$ & 0.006 & $1.13(0.95-1.35)$ & 0.175 & $1.32(1.09-1.60)$ & 0.004 \\
\hline \multirow[t]{3}{*}{ Wealth $^{\mathrm{d}}$} & Low & 1.00 & & 1.00 & & 1.00 & & 1.00 & \\
\hline & Middle & $0.87(0.65-1.18)$ & 0.369 & $0.79(0.58-1.08)$ & 0.133 & $1.23(1.04-1.46)$ & 0.014 & $1.14(0.96-1.36)$ & 0.139 \\
\hline & High & $0.92(0.67-1.26)$ & 0.593 & $0.72(0.51-1.03)$ & 0.069 & $1.41(1.20-1.66)$ & $<0.001$ & $1.16(0.96-1.40)$ & 0.122 \\
\hline \multirow[t]{2}{*}{ Location } & Urban & 1.00 & & 1.00 & & 1.00 & & 1.00 & \\
\hline & Rural & $0.85(0.66-1.11)$ & 0.235 & $0.89(0.67-1.19)$ & 0.443 & $0.85(0.74-0.98)$ & 0.026 & $1.03(0.89-1.20)$ & 0.693 \\
\hline \multirow[t]{3}{*}{ Social capital $^{\mathrm{e}}$} & Close relatives & $0.96(0.89-1.04)$ & 0.302 & $0.96(0.89-1.04)$ & 0.360 & $1.00(0.96-1.04)$ & 0.975 & $1.01(0.97-1.05)$ & 0.667 \\
\hline & Friends & $1.06(0.99-1.14)$ & 0.108 & $1.02(0.94-1.12)$ & 0.583 & $1.03(0.99-1.07)$ & 0.190 & $1.01(0.97-1.06)$ & 0.661 \\
\hline & Neighbours & $0.90(0.84-0.96)$ & 0.001 & $0.92(0.86-0.99)$ & 0.027 & $0.89(0.86-0.92)$ & $<0.001$ & $0.91(0.88-0.94)$ & $<0.001$ \\
\hline Alcohol & Never & 1.00 & & 1.00 & & 1.00 & & 1.00 & \\
\hline \multirow[t]{3}{*}{ consumption } & $\begin{array}{l}1-2 \text { times/month } \\
\text { or less }\end{array}$ & $0.99(0.71-1.37)$ & 0.942 & $0.96(0.69-1.35)$ & 0.822 & $1.35(1.13-1.60)$ & 0.001 & $1.29(1.08-1.54)$ & 0.005 \\
\hline & Once a week & $1.96(1.24-3.11)$ & 0.004 & $1.70(1.05-2.74)$ & 0.031 & $1.59(1.23-2.06)$ & $<0.001$ & $1.49(1.14-1.95)$ & 0.003 \\
\hline & $\begin{array}{l}2-3 \text { times/week } \\
\text { or more }\end{array}$ & $2.71(1.83-4.01)$ & $<0.001$ & $2.30(1.50-3.51)$ & $<0.001$ & $1.86(1.48-2.35)$ & $<0.001$ & $1.83(1.43-2.34)$ & $<0.001$ \\
\hline \multirow[t]{9}{*}{ Country } & Armenia & $0.57(0.30-1.10)$ & 0.093 & $0.61(0.31-1.18)$ & 0.143 & $0.62(0.45-0.85)$ & 0.003 & $0.72(0.52-1.00)$ & 0.048 \\
\hline & Azerbaijan & $1.41(0.88-2.26)$ & 0.149 & $1.68(0.98-2.86)$ & 0.058 & $0.44(0.31-0.62)$ & $<0.001$ & $0.60(0.42-0.87)$ & 0.007 \\
\hline & Belarus & $0.58(0.32-1.08)$ & 0.087 & $0.57(0.31-1.06)$ & 0.076 & $1.02(0.79-1.32)$ & 0.889 & $0.96(0.74-1.25)$ & 0.751 \\
\hline & Georgia & $0.37(0.19-0.73)$ & 0.004 & $0.46(0.23-0.94)$ & 0.032 & $0.43(0.31-0.59)$ & $<0.001$ & $0.55(0.39-0.77)$ & $<0.001$ \\
\hline & Kazakhstan & $1.25(0.77-2.02)$ & 0.368 & $1.30(0.79-2.13)$ & 0.302 & $1.18(0.92-1.51)$ & 0.204 & $1.31(1.02-1.70)$ & 0.037 \\
\hline & Kyrgyzstan & $1.55(0.98-2.45)$ & 0.060 & $1.70(1.02-2.81)$ & 0.040 & $1.05(0.81-1.35)$ & 0.734 & $1.40(1.06-1.84)$ & 0.018 \\
\hline & Moldova & $1.93(1.25-2.98)$ & 0.003 & $1.64(1.03-2.62)$ & 0.037 & $1.94(1.55-2.43)$ & $<0.001$ & $2.09(1.65-2.65)$ & $<0.001$ \\
\hline & Russia & 1.00 & & 1.00 & & 1.00 & & 1.00 & \\
\hline & Ukraine & $1.47(0.93-2.32)$ & 0.100 & $1.46(0.92-2.32)$ & 0.106 & $1.75(1.39-2.19)$ & $<0.001$ & $1.78(1.42-2.24)$ & $<0.001$ \\
\hline
\end{tabular}

a Adjusted for country.

b Mutually adjusted for all covariates in the model.

c Education was classified as: low (less than complete secondary education), middle (completed secondary education), high (incomplete or complete higher education).

d Principal component analysis was used to generate the wealth index based on the possession of 10 household assets.

e Social capital was assessed by asking how often the respondent met socially with close relatives, friends and neighbours with the answer options: (1) never, (2) less than once a month, (3) once a month, (4) several times a month, (5) once a week, (6) several times a week, (7) everyday. These three variables were included in the regression analysis as continuous variables.

though some research indicates that the predictors of male and female violent victimisation can vary (Stickley \& Carlson, 2010) as can its health effects (Romito \& Grassi, 2007). Nonetheless, the failure to find a significant relation between violence and male gender which is a common finding in the criminological literature (Sampson \& Lauritsen, 1994) does suggest that even the combined model may have lacked statistical power as a consequence of the very low frequency of violent victimisation. The cross-sectional nature of this study also means that it was impossible to determine the temporal ordering of events. For example, earlier research has linked criminal victimisation to a subsequent increase in alcohol consumption (Kilpatrick, Acierno, Resnick, Saunders \& Best, 1997). Finally, information was collected on victimisation within the confines of a large cross-country health survey. Although every

Table 3

The effects of criminal victimisation on health outcomes in nine countries of the former Soviet Union.

\begin{tabular}{|c|c|c|c|c|c|c|}
\hline Outcome & Exposure $^{a}$ & & OR $(95 \% \mathrm{CI})^{\mathrm{b}}$ & $P$-value & Adj.OR $(95 \% \mathrm{CI})^{\mathrm{c}}$ & $P$-value \\
\hline \multirow[t]{4}{*}{ Poor self-rated health } & Victim of physical violence & No & 1.00 & & 1.00 & \\
\hline & $(N=16117)$ & Yes & $1.62(1.19-2.19)$ & 0.002 & $2.49(1.74-3.55)$ & $<0.001$ \\
\hline & Victim of theft & No & 1.00 & & 1.00 & \\
\hline & $(N=16085)$ & Yes & $1.33(1.13-1.57)$ & 0.001 & $1.94(1.60-2.36)$ & $<0.001$ \\
\hline \multirow[t]{4}{*}{ Psychological distress ${ }^{\mathrm{d}}$} & Victim of physical violence & No & 1.00 & & 1.00 & \\
\hline & $(N=15149)$ & Yes & $2.43(1.85-3.20)$ & $<0.001$ & $2.85(2.13-3.80)$ & $<0.001$ \\
\hline & Victim of theft & No & 1.00 & & 1.00 & \\
\hline & $(N=15119)$ & Yes & $1.60(1.37-1.87)$ & $<0.001$ & $1.81(1.54-2.13)$ & $<0.001$ \\
\hline
\end{tabular}

\footnotetext{
a Refers to events which occurred in the past 12 months.

b Adjusted for country.

c Adjusted for sex, age, education, marital status, wealth, location, social capital, alcohol consumption, smoking, BMI, unemployment, and country.

d Psychological distress was defined as the highest quintile of a composite score based on 12 questions.
} 
effort was made (in conjunction with individual country representatives) to ensure the use of appropriate terms when the survey was designed, as violence can be culturally specific, that is, defined, understood and/or reported in different ways, this might have introduced bias into our study. To avoid this potential problem in the future, both quantitative and qualitative research methods should be used within the individual countries in this region to better understand the phenomenon of victimisation in terms of how it is defined, when and where it happens, who it happens to, as well as in relation to its effects on health.

Several demographic factors were associated with both forms of victimisation. Those who were younger and not married were at an increased risk of experiencing both violence and theft. This accords with a large body of research which has linked age (younger) and marital status (not married) to a higher risk of violent victimisation (Brennan et al., 2010; Sampson \& Lauritsen, 1994; Simon, Kresnow \& Bossarte, 2008), while demographic characteristics such as a younger age and living alone have also been previously linked to larceny and robbery (Cohen \& Cantor, 1980; Cohen, Cantor \& Kluegel, 1981). Our results would seem to provide some support for what have previously been termed the 'lifestyle/routine activity' theories of victimisation (Cohen \& Felson, 1979; Hindelang et al., 1978; Maxfield, 1987). These link demographic characteristics to different lifestyles and activities which increase exposure to victimisation risk situations. It has been suggested, for example, that those who are married are likely to have more 'home-centred activities' and that this might explain their lower victimisation rates (Cohen, Kluegel \& Land, 1981). The same differences in lifestyle might also be found among individuals with different levels of education (Pridemore \& Shkolnikov, 2004) which might explain why those with a low level of education had higher odds for experiencing violence in the current study. However, it is also possible that education may affect the risk of victimisation in other ways. Educational attainment has been linked to better cognitive (reasoning) and problem-solving skills (Hummer \& Lariscy, 2011; Jones-Webb \& Wall, 2008). This might be important in terms of reducing the risk of experiencing violent victimisation as arguments which become increasingly heated (and frequently involve alcohol) may underpin the occurrence of much interpersonal violence in at least some of the countries in this region (Pridemore \& Eckhardt, 2008).

The finding that one form of social capital - interacting with neighbours - was protective against both forms of victimisation accords with earlier research from the United States which highlighted that meeting neighbours both occasionally and more frequently was protective against violence, burglary, robbery and theft (Bellair, 1997; Patterson, 1991). This protective effect might emanate from the adoption of safer lifestyles by those interacting most with known others (Stickley \& Carlson, 2010). Neighbours can also act as a source of information about the occurrence of crime (Unger \& Wandersman, 1985), which may be protective. It is also possible that meeting with neighbours is a marker for greater cohesiveness within a community. This may be important for reduced crime as it has been suggested that such communities are more likely to have a higher degree of informal behavioural control that can act to lessen the possibility of criminal victimisation through such things as increased surveillance and intervention in disturbances (Bellair, 1997).

More frequent alcohol consumption increased the risk of experiencing both violence and theft. In relation to this finding, it is possible that drinking alcohol might increase the chance of becoming a target of crime in two ways. First, the pharmacological effects of alcohol might act to increase an individual's vulnerability to theft/robbery by decreasing cognitive awareness. Second, it may reduce one's ability to defend oneself against attack. However, the relationship between alcohol consumption and victimisation is complex. The association we observed between drinking and violent victimisation mirrors the result of an earlier study from Russia - where it was suggested that besides making individuals more vulnerable, alcohol can also act to fuel arguments that result in violence or even be linked to provocation that leads to violence (Stickley \& Pridemore, 2010).

The connection we observed between victimisation and poorer health accords with the results from an earlier study conducted in the Czech Republic, a former socialist country (Hraba, Lorenz, Pechačová \& Bao, 1999), and with an extensive body of literature from elsewhere linking victimisation to poorer physical and especially, psychological health. Although the exact way in which criminal victimisation impacts negatively on health outcomes, apart from physical injury, is uncertain, one mechanism that could link victimisation and worse health is stress. It has been suggested for example, that violence might be linked to a range of stressrelated somatic symptoms including fatigue, temporomandibular disorder, chronic muscle pain and irritable bowel syndrome (Crofford, 2007). If this association does exist, it may help explain why victimised respondents had worse self-rated health in the current study. As regards the connection we found between victimisation and poorer mental health, it is possible that this might result from the acute emotional and psychological distress that victimisation can induce directly (Resnick, Acierno \& Kilpatrick, 1997) which has been linked to shattered perceptions of personal invulnerability, the incomprehensibility of victimisation and feelings of powerlessness and helplessness (Janoff-Bulman \& Frieze, 1983).

Regardless of the specific mechanisms underlying the victimisation-poor health relation there are several factors which might act to exacerbate the effects of victimisation on health in the countries in this region. It is possible for example, that the high levels of institutional scepticism and distrust seen throughout the countries in the fSU (Mishler \& Rose, 1997; Stickley, Ferlander, et al., 2009) might be discouraging help-seeking following victimisation, as distrust in doctors has been cited as one reason for refusing treatment among some individuals in the countries in this region (Balabanova, Roberts, Richardson, Haerpfer \& McKee, 2012). Moreover, there is some suggestion that having to interact with the police is itself not only very stressful (Zernova, 2012), but that the police themselves may also be perpetrators of violent crime in some settings (Gerber \& Mendelson, 2008). Finally, the pressures induced by transition may have also acted to undermine the ties that have traditionally bound small groups of people (such as family and friends) together in some of our study countries (Twigg \& Schecter, 2003). If this is correct it may be having an especially detrimental effect as previous research has highlighted how most people rely on informal sources such as family and friends for help following criminal victimisation (McCart, Smith \& Sawyer, 2010) and that such social support can buffer the effects of victimisation on health (Kaniasty \& Norris, 1992).

In conclusion, this study has shown that many of the same demographic and other factors underpin different forms of criminal victimisation in the countries in the fSU and that being a victim of crime is associated with having worse self-rated and psychological health. Indeed, for those who fall prey to crime the effects can impact negatively across a range of differing domains (Hanson, Sawyer, Begle \& Hubel, 2010). Given this, the almost total absence of research on criminal victimisation and its effects on population health in the fSU suggests that, in addition to the adoption and expansion of policies that reduce rates of crime, more research is now urgently needed on this phenomenon. In particular, it is now essential to ascertain whether the association between victimisation and poor health is causal and, if so, what are its potential 
mechanisms and which interventions might mitigate its impact on health in ways that are contextually appropriate in the fSU.

\section{Acknowledgements}

The Health in Times of Transition (HITT) project was funded by the European Union's 7th Framework Programme (project HEALTH-F2-2009-223344). We are grateful to all members of the HITT study teams who participated in the coordination and organization of data collection for this article. The European Commission cannot accept any responsibility for any information provided or views expressed.

\section{References}

Balabanova, D., Roberts, B., Richardson, E., Haerpfer, C., \& McKee, M. (2012). Health care reform in the former Soviet Union: beyond the transition. Health Services Research, 47, 840-864.

Beaton, A., Cook, M., Kavanagh, M., \& Herrington, C. (2000). The psychological impact of burglary. Psychology, Crime E Law, 6, 33-43.

Bellair, P. E. (1997). Social interaction and community crime: examining the importance of neighbor networks. Criminology, 35, 677-704.

Boudreaux, E., Kilpatrick, D. G., Resnick, H. S., Best, C. L., \& Saunders, B. E. (1998). Criminal victimization, posttraumatic stress disorder, and comorbid psychopathology among a community sample of women. Journal of Traumatic Stress, 11 , $665-678$.

Brainerd, E. (1998). Market reform and mortality in transition economies. World Development, 26, 2013-2027.

Brainerd, E., \& Cutler, D. M. (2005). Autopsy on an empire: understanding mortality in Russia and the former Soviet Union. Journal of Economic Perspectives, $19,107-130$.

Breiding, M. J., Black, M. C., \& Ryan, G. W. (2008). Chronic disease and health risk behaviors associated with intimate partner violence - 18 U.S. states/territories, 2005. Annals of Epidemiology, 18, 538-544.

Brennan, I. R., Moore, S. C., \& Shepherd, J. P. (2010). Risk factors for violent victimisation and injury from six years of the British Crime Survey. International Review of Victimology, 17, 209-229.

Breslau, N., Peterson, E. L., Schultz, L. R., Chilcoat, H. D., \& Andreski, P. (1998). Major depression and stages of smoking: a longitudinal investigation. Archives of General Psychiatry, 55, 161-166.

Britt, C. L. (2001). Health consequences of criminal victimization. International Review of Victimology, 8, 63-73.

Campbell, J. C. (2002). Health consequences of intimate partner violence. Lancet, 359, 1331-1336.

Caucasus Research Resource Centres - Georgia. (2007). Migration and return in Georgia: Trends, assessments, and potential. Tbilisi: CRCR/European Commission. Chervyakov, V. V., Shkolnikov, V. M., Pridemore, W. A., \& McKee, M. (2002). The changing nature of murder in Russia. Social Science \& Medicine, 55, 1713-1724.

Cockerham, W. C., Hinote, B. P., \& Abbott, P. (2006). Psychological distress, gender, and health lifestyles in Belarus, Kazakhstan, Russia, and Ukraine. Social Science $\mathcal{E}$ Medicine, 63, 2381-2394.

Cohen, L. E., \& Cantor, D. (1980). The determinants of larceny: an empirical and theoretical study. Journal of Research in Crime and Delinquency, 17, 140-159.

Cohen, L. E., Cantor, D., \& Kluegel, J. R. (1981). Robbery victimization in the U.S.: an analysis of a nonrandom event. Social Science Ouarterly, 62, 644-657.

Cohen, L. E., \& Felson, M. (1979). Social change and crime rate trends: a routine activity approach. American Sociological Review, 44, 588-608.

Cohen, L. E., Kluegel, J. R., \& Land, K. C. (1981). Social inequality and predatory criminal victimization: an exposition and test of a formal theory. American Sociological Review, 46, 505-524.

Crofford, L. J. (2007). Violence, stress, and somatic syndromes. Trauma, Violence, $\mathcal{E}$ Abuse, 8, 299-313.

Earle, J. S., \& Sabirianova, K. Z. (2002). How late to pay? Understanding wage arrears in Russia. Journal of Labor Economics, 20, 661-707.

Ellsberg, M., Jansen, H. A. F. M., Heise, L., Watts, C. H., Garcia-Moreno, C., \& WHO Multi-country Study on Women's Health and Domestic Violence against Women Study Team. (2008). Intimate partner violence and women's physical and mental health in the WHO multi-country study on women's health and domestic violence: an observational study. Lancet, 371, 1165-1172.

Faergemann, C., Lauritsen, J. M., Brink, O., Skov, O., \& Mortensen, P. B. (2009). Demographic and socioeconomic risk factors of adult violent victimization from an accident and emergency department and forensic medicine perspective: a register-based case-control study. Journal of Forensic and Legal Medicine, 16, 11-17.

Foglesong, T. S., \& Solomon, P. H., Jr. (2001). Crime, criminal justice, and criminology in post-Soviet Ukraine. Washington, D. C.: National Institute of Justice.

Gavrilova, N. S., Semyonova, V. G., Evdokushkina, G. N., \& Gavrilov, L. A. (2000). The response of violent mortality to economic crisis in Russia. Population Research and Policy Review, 19, 397-419.
Gerber, T. P., \& Mendelson, S. E. (2008). Public experiences of police violence and corruption in contemporary Russia: a case of predatory policing? Law E Society Review, 42, 1-44.

Gerry, C. J., Kim, B. Y., \& Li, C. A. (2004). The gender wage gap and wage arrears in Russia: evidence from the RLMS. Journal of Population Economics, 17, 267-288.

Gilinskiy, Y. (2006). Crime in contemporary Russia. European Journal of Criminology, 3, 259-292.

Hanson, R. F., Sawyer, G. K., Begle, A. M., \& Hubel, G. S. (2010). The impact of crime victimization on quality of life. Journal of Traumatic Stress, 23, 189-197.

Hindelang, M. J., Gottfredson, M. R., \& Garofalo, J. (1978). Victims of personal crime: an empirical foundation for a theory of personal victimization. Cambridge, Mass: Ballinger Publishing Company.

Holmes, L. (2009). Crime, organised crime and corruption in post-communist Europe and the CIS. Communist and Post-Communist Studies, 42, 265-287.

Hraba, J., Lorenz, F. O., Pechačová, Z., \& Bao, W. N. (1999). Criminal victimization and distress in the Czech Republic. Journal of Interpersonal Violence, 14, 1030-1054.

Hummer, R. A., \& Lariscy, J. T. (2011). Educational attainment and adult mortality. In R. G. Rogers, \& E. M. Crimmins (Eds.), International handbook of adult mortality (pp. 241-261). Dordrecht: Springer.

Janoff-Bulman, R., \& Frieze, I. H. (1983). A theoretical perspective for understanding reactions to victimization. Journal of Social Issues, 39, 1-17.

Jones-Webb, R., \& Wall, M. (2008). Neighborhood racial/ethnic concentration, social disadvantage, and homicide risk: an ecological analysis of 10 U.S. cities. Journal of Urban Health, 85, 662-676.

Kaniasty, K., \& Norris, F. H. (1992). Social support and victims of crime: matching event, support, and outcome. American Journal of Community Psychology, 20, $211-241$.

Karstedt, S. (2003). Legacies of a culture of inequality: the Janus face of crime in post-communist countries. Crime, Law \& Social Change, 40, 295-320.

Kilpatrick, D. G., \& Acierno, R. (2003). Mental health needs of crime victims: epidemiology and outcomes. Journal of Traumatic Stress, 16, 119-132.

Kilpatrick, D. G., Acierno, R., Resnick, H. S., Saunders, B. E., \& Best, C. L. (1997). A 2-year longitudinal analysis of the relationships between violent assault and substance use in women. Journal of Consulting and Clinical Psychology, 65, 834-847.

Kilpatrick, D. G., Best, C. L., Veronen, L. J., Amick, A.,E., Villeponteaux, L. A., \& Ruff, G. A. (1985). Mental health correlates of criminal victimization: a random community survey. Journal of Consulting and Clinical Psychology, 53, 866-873.

Koss, M. P., Woodruff, W. J., \& Koss, P. G. (1990). Relation of criminal victimization to health perceptions among women medical patients. Journal of Consulting and Clinical Psychology, 58, 147-152.

Leon, D. A., Saburova, L., Tomkins, S., Andreev, E., Kiryanov, N., McKee, M., et al. (2007). Hazardous alcohol drinking and premature mortality in Russia: a population based case-control study. Lancet, 369, 2001-2009.

Leon, D. A., Shkolnikov, V. M., \& McKee, M. (2009). Alcohol and Russian mortality: a continuing crisis. Addiction, 104, 1630-1636.

McCart, M. R., Smith, D. W., \& Sawyer, G. K. (2010). Help seeking among victims of crime: a review of the empirical literature. Journal of Traumatic Stress, 23,198-206.

McKee-Ryan, F. M., Song, Z. L., Wanberg, C. R., \& Kinicki, A. J. (2005). Psychological and physical well-being during unemployment: a meta-analytic study. Journal of Applied Psychology, 90, 53-76.

Manderbacka, K., Lahelma, E., \& Martikainen, P. (1998). Examining the continuity of self-rated health. International Journal of Epidemiology, 27, 208-213.

Maxfield, M. G. (1987). Lifestyle and routine activity theories of crime: empirical studies of victimization, delinquency, and offender decision-making. Journal of Quantitative Criminology, 3, 275-282.

Mishler, W., \& Rose, R. (1997). Trust, distrust and skepticism: popular evaluations of civil and political institutions in post-communist societies. Journal of Politics, 59, $418-451$.

Murphy, M. (2011). Adult mortality in the former Soviet Union. In R. G. Rogers, \& E. M. Crimmins (Eds.), International handbook of adult mortality (pp. 83-100). Dordrecht: Springer.

Norris, F. H., \& Kaniasty, K. (1994). Psychological distress following criminal victimization in the general population: cross-sectional, longitudinal, and prospective analyses. Journal of Consulting and Clinical Psychology, 62, 111-123.

Olofsson, N., Lindqvist, K., \& Danielsson, I. (2012). Fear of crime and psychological and physical abuse associated with ill health in a Swedish population aged 6584 years. Public Health, 126, 358-364.

Patterson, E. B. (1991). Poverty, income inequality, and community crime rates. Criminology, 29, 755-776.

Pridemore, W. A., \& Eckhardt, K. (2008). A comparison of victim, offender, and event characteristics of alcohol- and non-alcohol-related homicides. Journal of Research in Crime and Delinquency, 45, 227-255.

Pridemore, W. A., \& Shkolnikov, V. M. (2004). Education and marriage as protective factors against homicide mortality: methodological and substantive findings from Moscow. Journal of Quantitative Criminology, 20, 173-187.

Resnick, H. S., Acierno, R., \& Kilpatrick, D. G. (1997). Health impact of interpersonal violence. 2: medical and mental health outcomes. Behavioral Medicine, 23, 65-78.

Robbins, I. (2007). Crime victims. In (2nd ed.)., Encyclopedia of stress, Vol. 1 A-E (pp. 659-662) Amsterdam: Elsevier.

Roberts, B., Stickley, A., Petticrew, M., \& McKee, M. (2012). The influence of concern about crime on levels of psychological distress in the former Soviet Union. Journal of Epidemiology and Community Health, 66, 433-439.

Robinson, F., \& Keithley, J. (2000). The impacts of crime on health and health services: a literature review. Health, Risk \& Society, 2, 253-266. 
Romito, P., \& Grassi, M. (2007). Does violence affect one gender more than the other? The mental health impact of violence among male and female university students. Social Science \& Medicine, 65, 1222-1234.

Sampson, R. J., \& Lauritsen, J. L. (1994). Violent victimization and offending: individual-, situational-, and community-level risk factors. In A. J. Reiss, Jr., \& J. A. Roth (Eds.). Social influences: Vol. 3. Understanding and preventing violence (pp. 1-114). Washington, D. C.: National Academy Press.

Schwartz, G. (2003). Employment restructuring in Russian industrial enterprises: confronting a 'paradox'. Work, Employment and Society, 17, 49-72.

Shapland, J., \& Hall, M. (2007). What do we know about the effects of crime on victims? International Review of Victimology, 14, 175-217.

Simon, T. R., Kresnow, M. J., \& Bossarte, R. M. (2008). Self-reports of violent victimization among U.S. adults. Violence and Victims, 23, 711-726.

Slade, G. (2012). Georgia's war on crime: creating security in a post-revolutionary context. European Security, 21, 37-56.

Solomon, P. H., Jr., \& Foglesong, T. S. (2000). The two faces of crime in post-Soviet Ukraine. East European Constitutional Review, 9, 72-76.

Stickley, A., \& Carlson, P. (2010). Factors associated with non-lethal violent victimization in Sweden in 2004-2007. Scandinavian Journal of Public Health, 38, 404-410.

Stickley, A., Ferlander, S., Jukkala, T., Carlson, P., Kislitsyna, O., \& Mäkinen, I. H. (2009). Institutional trust in contemporary Moscow. Europe-Asia Studies, 61, 779-796.

Stickley, A., Leinsalu, M., \& Razvodovsky, Y. E. (2009). Homicide in post-Soviet Belarus: urban-rural trends. European Journal of Public Health, 19, 117-120.

Stickley, A., \& Pridemore, W. A. (2010). The effects of binge drinking and socia capital on violent victimisation: findings from Moscow. Journal of Epidemiology and Community Health, 64, 902-907.
Stuckler, D., King, L., \& McKee, M. (2009). Mass privatisation and the postcommunist mortality crisis: a cross-national analysis. Lancet, 373, 399-407.

Thacher, D. (2004). The rich get richer and the poor get robbed: inequality in U.S. criminal victimization, 1974-2000. Journal of Quantitative Criminology, 20, 89-116.

Twigg, J. L., \& Schecter, K. (2003). Introduction. In J. L. Twigg, \& K. Schecter (Eds.), Social capital and social cohesion in post-Soviet Russia (pp. 3-15). Armonk, New York: M. E. Sharpe.

Unger, D. G., \& Wandersman, A. (1985). The importance of neighbors: the social, cognitive, and affective components of neighboring. American Journal of Community Psychology, 13, 139-169.

UNODC. (2012). United Nations office on drugs and crime. Crime and Criminal Justice Statistics. Available at: http://www.unodc.org/unodc/en/data-and-analysis/ statistics/crime.html Accessed 06.09.12.

Van Dijk, J., \& Chanturia, T. (2011). Georgian crime trends in an international perspective; a secondary analysis of the 2010/2011 Crime and Security Surveys in Georgia. Vienna: Human Dynamics.

Walberg, P., McKee, M., Shkolnikov, V., Chenet, L., \& Leon, D. A. (1998). Economic change, crime, and mortality crisis in Russia: regional analysis. BMJ, 317, 312-318.

World Bank. (2005). Dying too young: Addressing premature mortality and ill health due to non-communicable diseases and injuries in the Russian Federation. Washington D. C.: Europe and Central Asia Human Development Department/ The World Bank.

World Health Organization. (2012). European health for all database (HFA-DB). Available at: http://data.euro.who.int/hfadb/ Accessed 23.09.12.

Zernova, M. (2012). Coping with the failure of the police in post-Soviet Russia: findings from one empirical study. Police Practice and Research, 13, 474-486. 